\title{
Syngas Compositions, Cold Gas and Carbon Conversion Efficiencies for Different Coal Gasification Processes and all Coal Ranks
}

\author{
Said MA Ibrahim* and Mostafa EM Samy \\ Faculty of Engineering, Department of Mechanical Engineering, Al-Azhar University, Egypt
}

*Corresponding author: Said MA Ibrahim and also in citation, Faculty of Engineering, Department of Mechanical Engineering, AlAzhar University, Egypt

\begin{abstract}
This Paper presents comparison of syngas compositions, for all coal ranks, as produced from different types of coal gasification processes currently in use, namely entrained flow, fluidized bed, and fixed bed gasifiers. Cold gas and carbon conversion efficiencies were investigated. The syngas composition varies with the applied gasification process. The importance of this research arises from the fact that gasifiers produce the environmentally clean fuel required to run any Integrated Gasification Combined Cycle power system. A procedure was conducted to get estimates for bituminous coal. It is important to have knowledge of the chemical reactions which take place in each gasifier and the raw syngas produced from the specific reaction involved to develop an Integrated Coal Gasification Combined Power Generation plant with $\mathrm{CO}_{2}$ recovery in order to increase the cycle efficiency and mitigate $\mathrm{CO}_{2}$ emission and other pollutants. The results indicate that the entrained flow gasifier is the dominant one.
\end{abstract}

Keywords: Syngas; Coal gasification; Cold gas efficiency; Coal conversion efficiency; Gasifiers

\section{Introduction}

Gasifiers in an Integrated Gasification Combined Cycle power plant (IGCC) are the heart of the system since they are the producers of the syngas fuel required to operate the plant. Their efficiency and availability are determining factors not only for their design but also for the IGCC system. The study and comparison of different gasifiers are essential for the efficient operation of IGCC plants.

In gasification, organic (carbonaceous) feeds are converted into $\mathrm{CO}, \mathrm{CO}_{2}$, and $\mathrm{H}_{2}$ by processing the feed at elevated temperatures $\left(>700^{\circ} \mathrm{C}\right)$, without combustion, with a controlled amount of oxygen and/or steam. The produced gas mixture (synthesis gas or syngas) is a fuel. The power generated from the combustion of the syngas, is a source of renewable energy if the obtained gaseous products are produced from a source other than a fossil fuel, e.g. biomass [1].

The main advantage of coal gasification is the utilization of the syngas which is actually more efficient in its burning as compared to the direct combustion of the solid coal because of: (1) the possibility of combustion at higher temperatures, i.e. increasing the thermal efficiency, (2) its use in fuel cells, (3) the possibility to produce methanol and hydrogen, and (4) its conversion via the Fischer-Tropsch (FT) process into a range of synthesis liquid fuels suitable for use in gasoline or diesel engines [1]. In addition, coal is still a virgin resource because of its large reserves in many countries around the world and thus it is greatly more secured than oil and natural gas. It is not subjected to the unexpected price variations in comparison.

The high temperature process produces corrosive ash elements, including metal chlorides and potassium salts, which allow clean gas production from otherwise problematical fuels [1]. However, the ash content in coal is the top important factor in selecting coal since it represents the greatest problem in the operation and performance of a slagging gasifier. Gasifiers need to be efficient for the purpose of increasing the availability of the IGCC system, which is a demanding requirement. It is essential to avoid high ash content in the chosen coal because its melting needs more heat, and hence additional coal and $\mathrm{CO}$ are combusted. This increases the amount 
of $\mathrm{CO}_{2}$ in the syngas and a reduction in the cold gas efficiency as a consequence of the high ash content.

Coal gasification power plants are cleaner compared to pulverized coal (PC) combustion plants, since they produce less sulphur and nitrogen oxides pollutants. Therefore, gasification is an appealing technology which enables the utilization of both relatively inexpensive and expensive coal reserves, in addition to reducing down the environmental impact. In fact, the increased mounting interest in coal gasification announces two changes in the electricity generation arena: (1) the maturity of coal gasification technology, and (2) the incredibly low air emissions from IGCC power stations, and better lower cost control of greenhouse gases than that for other coal fired plants [1].

\section{The Gasification Process}

The real reactions associated with the gasification process are immensely complicated and change with the feed material properties [2].

The gasification of coal comprises three chief steps, as shown in Figure 1: (a) pyrolysis and devolatilization, (b) volatiles cracking and combustion, and (c) char gasification. These processes are explained briefly.

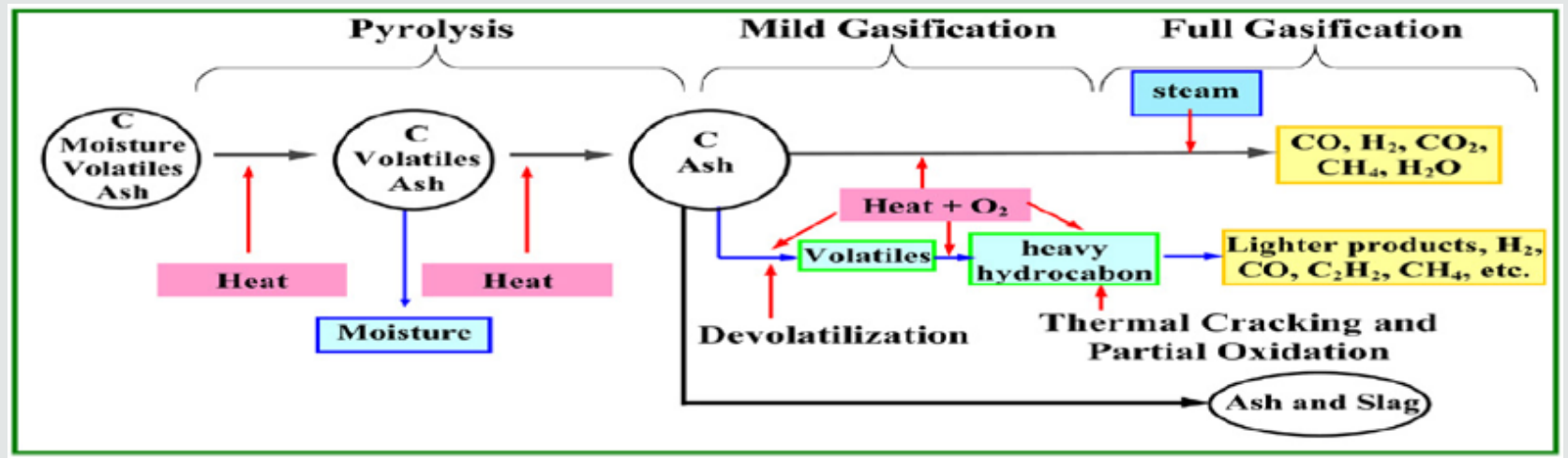

Figure 1: Main steps of coal particles gasification (sulfur and minerals are not included) [2].

\section{Pyrolysis and Devolatilization}

The interaction between pyrolysis and gasification under various conditions of heating is depicted in Figure 2. If the heating is slow then the pyrolysis reactions start at about $350^{\circ} \mathrm{C}$. The gasification reaction of volatile matters (VM) and char with steam is rather slow at such temperature. The concentration of volatiles outside the coal particle increases quickly, and gasification only takes place after devolatilization is accomplished. However, in case the heating rate is high, then both pyrolysis and gasification occur concurrently, so that high concentration of volatiles is never permitted to build up. This explains why a clean gas in such a short time is produced from high-temperature entrained-flow gasifiers. In Ref. [3], it is indicated that in contrast with a counter flow moving-bed process, where lump coal is employed, the rate of heating is slow and a high volatiles concentration grows up and discarded unreacted from the reactor by the syngas.

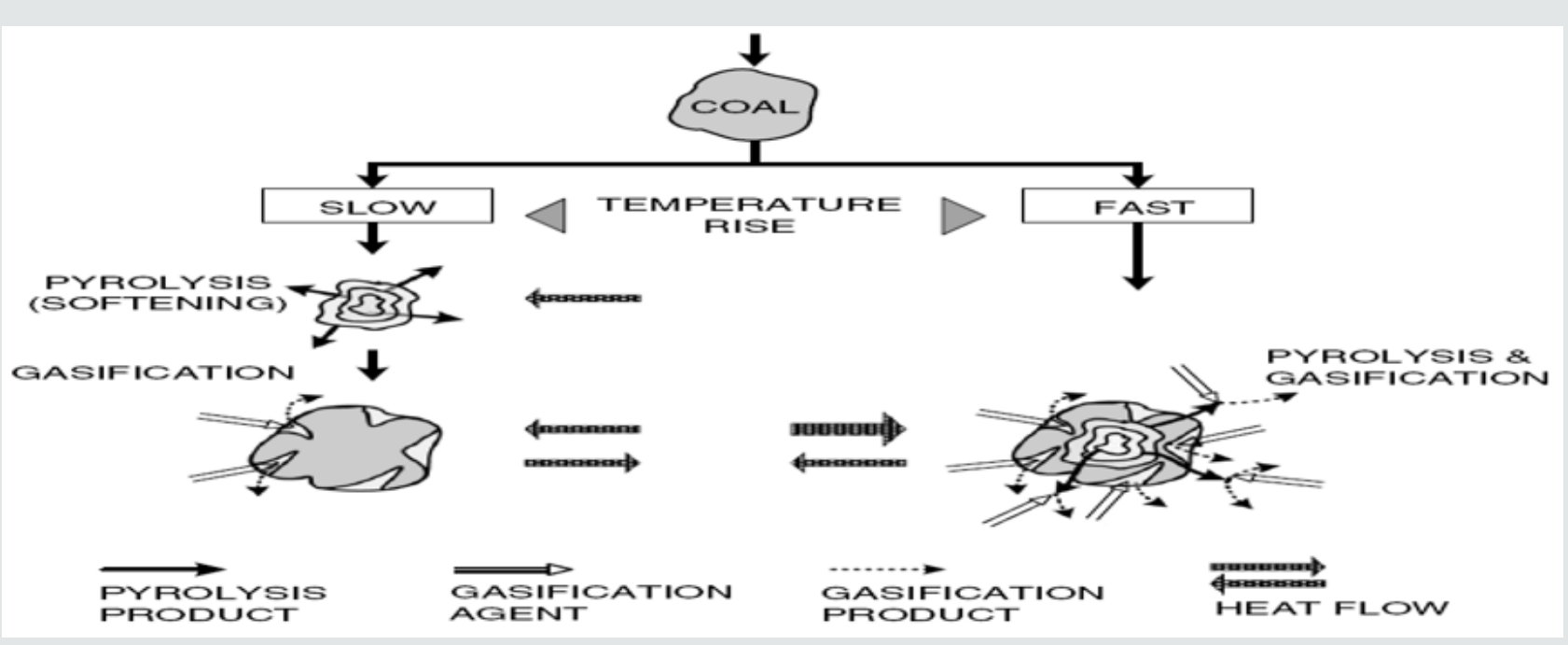

Figure 2: Effect of heating rate on the gasification process [3]. 


\section{Volatiles Combustion}

The devolatilization of coal produces multi species, which include tars, hydrocarbon liquids, and gases such as $\mathrm{CH}_{4}, \mathrm{CO}, \mathrm{CO}_{2}$, $\mathrm{H}_{2}, \mathrm{H}_{2} \mathrm{O}, \mathrm{HCN}$, and so on. These react with the oxidant surrounding the coal particle. The extent to which the oxidant is completely or partially depleted depends on the quantities of volatiles produced [3].

In combustion, where there is excess of oxygen, the volatiles are completely combusted. The moderating effect of carbon dioxide and water vapour reduces the temperature. In gasification the recycled gas contains notable amounts of carbon monoxide and hydrogen (up to $90 \%$ for an oxygen-blown gasifier) which causes tremendously high local temperatures, in case it comes into contact with the oxidant [3].

\section{Coal Gasification}

Gasification commences under shortage of oxygen. Coal is first heated in a closed chamber where it undertakes a pyrolysis process at temperatures over $400^{\circ} \mathrm{C}$. During pyrolysis, hydrogen rich VM is released, together with tar, phenols, and gaseous hydrocarbons. Then, char is gasified, with the liberation of gases, tar vapours, and solid residues. The ruling reactions subsist of partial oxidation of char, which produces a syngas with high fractions of $\mathrm{H}_{2}$ and $\mathrm{CO}$. The process happens at temperatures between 800 and $1800^{\circ} \mathrm{C}$ Exact operating conditions depend on coal type, properties of the resulting ash, and the gasification technology. The oxidant is the highly important variable in the gasification process. It can be either air or pure oxygen in case the process includes an air separation unit (ASU) for $\mathrm{O}_{2}$ production. The deployment of an ASU adds cost to the power plant.

If the coal is heated externally, the process is termed "allothermal," while "autothermal" process assumes heating of coal by means of exothermal chemical reactions undergoing inside the gasifier. Oxygen and water molecules oxidize the coal and produce a gaseous mixture of $\mathrm{CO}_{2}, \mathrm{CO}, \mathrm{H}_{2} \mathrm{O}$ vapour, $\mathrm{H}_{2}$, and $\mathrm{CH}_{4}$. Some byproducts like tar and phenols are also possible end products, depending on the type of the employed gasification technology. The likely wanted end product is usually syngas (i.e., a combination of $\mathrm{H}_{2}+\mathrm{CO}$ ), but the released coal gas may be further refined to produce extra quantities of $\mathrm{H}_{2}$, according to: $3 \mathrm{C}$ (coal) $+\mathrm{O}_{2}+\mathrm{H}_{2} \mathrm{O}$ $\rightarrow \mathrm{H}_{2}+3 \mathrm{CO}[4]$.

\section{Char Gasification}

As only char and ash left, the char particles sustain two important endothermic, heterogeneous gasification reactions: (1) the Boudouard reaction: $\mathrm{C}(\mathrm{s})+\mathrm{CO}_{2} \leftrightarrow 2 \mathrm{CO}$ (or, more specifically, the reverse Boudouard reaction, and it is also known as carbon dioxide-char gasification), and (2) the $\mathrm{C}(\mathrm{s})+\mathrm{H}_{2} \mathrm{O}(\mathrm{g}) \rightarrow \mathrm{CO}+\mathrm{H}_{2}$ or $\mathrm{C}(\mathrm{s})+2 \mathrm{H}_{2} \mathrm{O}(\mathrm{g}) \rightarrow \mathrm{CO}_{2}+2 \mathrm{H}_{2}$ reactions (also named steam-char gasification), where $s$ and g refer to solid and gas, respectively. Both reactions are endothermic [2].

The steam-char reaction is the supreme contributor to the production of both $\mathrm{H}_{2}$ and $\mathrm{CO}$, which are the primary reactive constituents of the syngas [2].

\section{Water-Gas Shift (WGS)Process Inside Gasifiers}

The water-gas shift reaction is an equilibrium process: $\mathrm{CO}+$ $\mathrm{H}_{2} \mathrm{O}(\mathrm{g}) \leftrightarrow \mathrm{CO}_{2}+\mathrm{H}_{2}$. The forward reaction is exothermic, in which $\mathrm{CO}$ and steam are converted to $\mathrm{H}_{2}$ and $\mathrm{CO}_{2}$. The forward reaction is energetic at temperatures less than $700^{\circ} \mathrm{C}$. At higher temperatures, near $1000^{\circ} \mathrm{C}$, the net reaction is slow and negligible. More than $1200^{\circ} \mathrm{C}$, the backward reaction becomes commanding. The reaction rate of the WGS is usually slow without using catalysts; however, in the gasifier, the reaction rate is usually enhanced by the catalytic effect of metallic components in coal. In gasifiers which utilize the quench method to cool down the syngas to near $200^{\circ} \mathrm{C}$, the residence time is very short to achieve any remarkable forward WGS reaction, despite that the equilibrium constant value is large at low temperatures, because the catalytic effect from metals in coal is feeble in the quenched syngas since most of the metals have become molten slag, which is extracted during the gasification process, before quenching takes place [2].

\section{Methanation}

The methanation reaction $\left[\mathrm{C}+2 \mathrm{H}_{2} \rightarrow \mathrm{CH}_{4}\right]$ is predominantly exothermic and pressure favourable, so it is generally inactive in high-temperature atmospheres, for instance in high-temperature entrained flow gasifiers [2].

\section{Types of Gasifiers}

Detailed descriptions of gasifier types and their operation can be found in many references. Operating data and innovative gasifiers studied prior to the 1980s are reported in some early studies. Recent approaches to gasification such as catalytic, molten salt, plasma, or secondary heated systems are dealt with elsewhere. Only the major gasifiers in use today are described. It is suggested that the foremost gasifier types are moving bed, fluidized bed, and entrained flow ones [5].

\section{Fixed Bed Gasifier}

A fixed bed gasifier is illustrated in Figure 3 The coal to ash and gas production schemes along the gasifier as the temperature varies is shown. These gasifiers are counter current flow ones; coal is fed at the top and the oxidant from the bottom. As the coal slowly proceeds down through the gasifier, it is gasified and the resulting ash drops out of the bottom. The counter current flow design allows the utilization of the heat of reaction from the gasification reactions to preheat the coal before its entrance to the gasification reaction zone. Consequently, the temperature of the syngas exiting the gasifier is remarkably less than the temperature required for total conversion of coal [6]. 

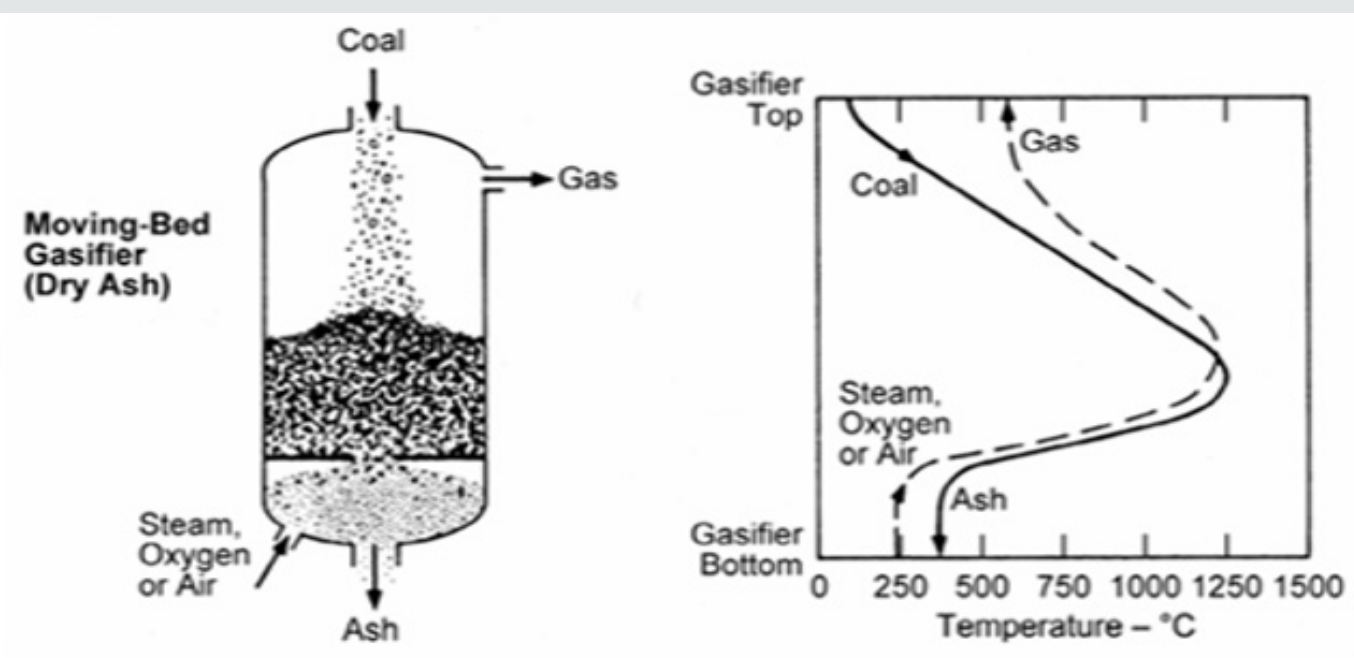

Figure 3: A fixed bed gasifier [6].

These features are notable in such gasifiers: the residence time of coal inside may be of the order of hours, low oxidant requirements, relatively high content of $\mathrm{CH}_{4}$ in the resulting gas, production of hydrocarbon liquids, such as oils and tars, high cold gas thermal efficiency when including the heating value of the hydrocarbon liquid, limited ability to handle fines, and special requirements for handling caking coal. Fixed bed gasifiers are still in use and have long industrial experience as the so named Lurgi type. However, reliable but are not suitable for one large scale gasifier. Recently a Lurgi of 1600 ton/day capacity was manufactured [7].

\section{Fluidized Bed Gasifier}

Figure 4 shows a fluidized bed gasifier. The figure illustrates how coal is converted into ash and the gas production across the gasifier as the temperature goes up. It is a back-mixed or wellstirred reactor where there is a consistent mixture of fresh coal particles mixed with older ones, some of which are partially gasified, and some are totally gasified. The mixing regime allows consisting temperatures throughout the bed. The gas flow into the reactor (oxidant, steam, recycled syngas) must be adjusted such that to suspend coal particles within the bed but not too high to entrain them out. As the gasified coal particles gets smaller and lighter, they will escape from the gasifier. In order to avoid particle agglomeration, it is important to ensure that the temperatures within the bed to be lower than the initial ash fusion temperature of coal [6].
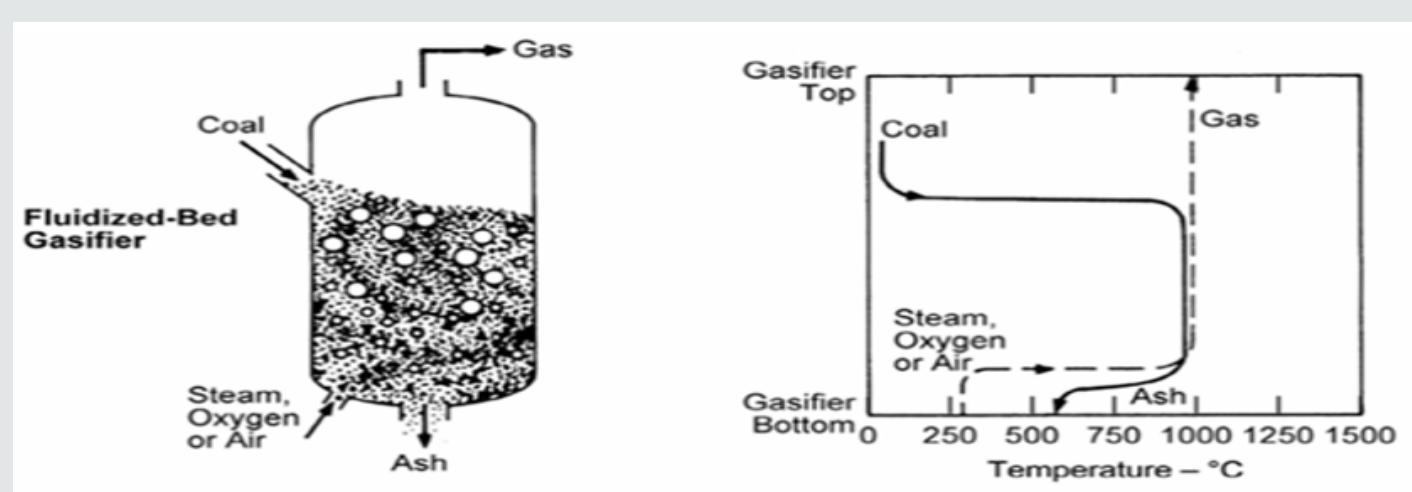

Figure 4: A fluidized bed gasifier [6].

A cyclone downstream the gasifier will capture the larger particles that are entrained out and return them back to the bed. The residence time of coal particles in these gasifiers is shorter than that in a moving bed one [6]. The main characteristics of these gasifiers are extensive solids recycling, uniform and moderate temperature, and moderate oxygen and steam requirements. Fluidized-bed gasifiers have been developed for the gasification of low-grade fuels or feed stock. The working principle of the fluidized bed embraces even distribution of oxidant through the reactor. Gas bubbles tend to flow via the less congested area, and this results in the existence of a dead zone inside the reactor. This creates difficulties in scaling up design and operation. Most distinguished fluidized-bed examples are fluidized bed boiler and waste pyrolysis plants [7]. 


\section{Entrained Flow Gasifier}

Figure 5 shows a diagram of an entrained flow gasifier. The figure gives the coal gas conversion and gas production along the reactor as a function of temperature. Co-current flow of pulverized coal and oxidant are injected into the reactor. The coal is rapidly

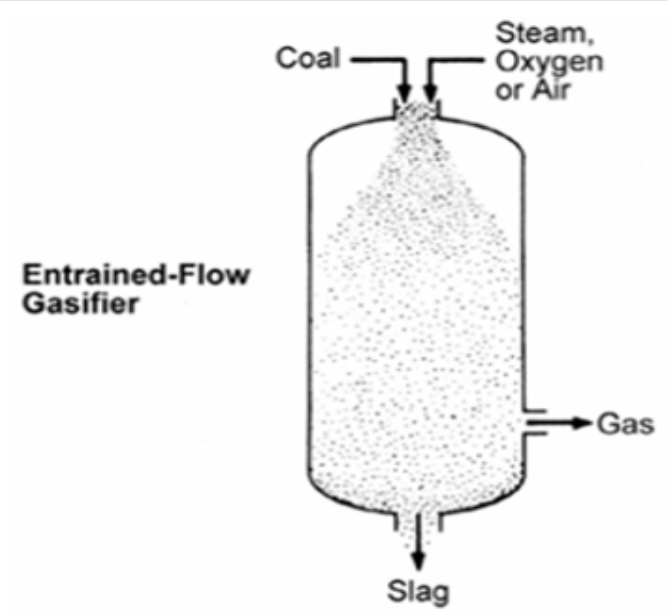

heated up and reacts with the oxidant. The residence time in these gasifiers is of the order of seconds. Because of this short time, such gasifiers must perform at high temperatures in order to attain high carbon conversion efficiency. Therefore, shows that the majority of entrained flow gasifiers employ oxygen rather than air and operate above the slagging temperature of coal [6].

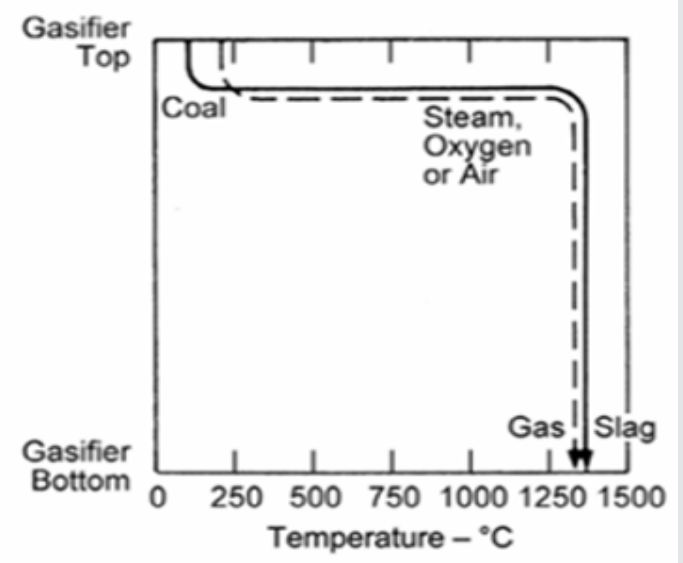

Figure 5: A fluidized bed gasifier [6].

Properties of entrained flow gasifiers include: high-temperature slagging performance, entrainment of some molten slag in the raw syngas, relatively large oxidant requirements, vast chunk of sensible heat in the raw syngas, and the potential to gasify all coal ranks, caking characteristics, or degree of fines.

The processes that need a high throughput capacity in a single reactor generally use entrained bed type, as in IGCC, since the reactor size can be reduced by the fast residence time (typically less than $5 \mathrm{sec}$ ) as well as by high pressure. Although large scale operation of entrained bed gasifiers have been successfully operated commercially, however, the experience is not long enough as in the case of fixed or fluidized bed gasifiers. It is concluded that the foremost disadvantage of entrained bed gasifier is its high capital cost due to the compact configuration of parts [7].

\section{Concluding Remarks on Gasifiers}

From the above discussions it is concluded that the favourable is the entrained flow one because:

a) The residence time is too short and in the order of second so it must operate at elevated temperatures to attain high carbon conversion efficiency.

b) It produces a clean gas in a short time as a result of operating at high temperature.

c) Large scale performance due to the short residence time and high carbon conversion efficiency, thus increasing both the throughput coal and yield abundantly. d) It increases the gas velocity which can reach 80-100 m/s.

e) The manufacturing cost is less compared to other types of gasifiers.

f) Low hydrocarbon because of the high temperature.

g) High $\mathrm{CO}_{2}$ capture because of the high $\mathrm{CO}$ in syngas.

h) None or very little tar formation because it is a downdraft gasifier.

i) The radiant syngas cooling can increase the cycle efficiency by $4-5 \%$ over full quench types.

Gasifiers need further improvements and developments in order to increase their efficiencies and performance for more availability of IGCC systems.

\section{Methodology of Calculations}

During the gasification of solid carbon, whether in the form of coal, coke, or char, the main chemical reactions are those associated with $\mathrm{C}, \mathrm{CO}, \mathrm{CO}_{2}, \mathrm{H}_{2}, \mathrm{H}_{2} \mathrm{O}$ (or steam), and $\mathrm{CH}_{4}$. These reactions are:

Combustion reactions

$$
\begin{aligned}
& \mathrm{C}+1 / 2 \mathrm{O}_{2}=\mathrm{CO}-111 \mathrm{MJ} / \mathrm{kmol}(1) \\
& \mathrm{CO}+1 / 2 \mathrm{O}_{2}=\mathrm{CO}_{2}-283 \mathrm{MJ} / \mathrm{kmol}(2) \\
& \mathrm{H}_{2}+1 / 2 \mathrm{O}_{2}=\mathrm{H}_{2} \mathrm{O}-242 \mathrm{MJ} / \mathrm{kmol} \mathrm{(3)}
\end{aligned}
$$

The Boudouard reaction 


$$
\mathrm{C}+\mathrm{CO}_{2}=2 \mathrm{CO}+172 \mathrm{MJ} / \mathrm{kmol}(4)
$$

The water gas reaction

$$
\mathrm{C}+\mathrm{H}_{2} \mathrm{O}=\mathrm{CO}+\mathrm{H}_{2}+131 \mathrm{MJ} / \mathrm{kmol}(5)
$$

The methanation reaction

$$
\mathrm{C}+2 \mathrm{H}_{2}=\mathrm{CH}_{4}+75 \mathrm{MJ} / \mathrm{kmol}(6)
$$

As reactions with free oxygen are all complete under gasification conditions, reactions (1), (2) and (3) do not need to be considered in determining an equilibrium syngas composition. The three heterogeneous (i.e. gas and solid phase) reactions (4), (5) and (6) are sufficient. In general, we are concerned with situations where the carbon conversion is also essentially complete. Under these circumstances, Equations (4), (5), and (6) can be reduced to these two homogeneous gas reactions:

The water gas shift reaction

$$
\mathrm{CO}+\mathrm{H}_{2} \mathrm{O}=\mathrm{CO}_{2}+\mathrm{H}_{2}+41 \mathrm{MJ} / \mathrm{kmol}(7)
$$

The steam methane reforming reaction

$$
\mathrm{CH}_{4}+\mathrm{H}_{2} \mathrm{O}=\mathrm{CO}+3 \mathrm{H}+206 \mathrm{MJ} / \mathrm{kmol}(8)
$$

Note that by subtracting the moles and heat effects from reaction (4) from those in reaction (5), one obtains reaction (7), and by subtracting reaction (6) from (5), one obtains reaction (8). Thus reactions (7) and (8) are implicit in reactions (4), (5), and (6) but not the other way around. Three independent equations always contain more information than two. Reactions (1), (4), (5), and (6) describe the four ways in which a carbonaceous or hydrocarbon fuel can be gasified. Reaction (4) is important for the production of pure $\mathrm{CO}$ when gasifying pure carbon with an $\mathrm{O}_{2} / \mathrm{CO}_{2}$ mixture. Reaction (5) plays a predominant role in the water gas process. Reaction (6) is the basis of all hydrogenating gasification processes. But most gasification processes rely on a balance between reactions (1) (partial oxidation) and (5) (water gas reaction). For real fuels (including coal, which also contains hydrogen), the overall reaction can be written as:

$$
\mathrm{C}_{\mathrm{n}} \mathrm{H}_{\mathrm{n}}+\mathrm{n} / 2 \mathrm{O}_{2}=\mathrm{nCO}+\mathrm{m} / 2 \mathrm{H}_{2}(9)
$$

Where

- For gas, as pure methane, $m=4$ and $n=1$, hence $m / n=4$

- For oil, $\mathrm{m} / \mathrm{n}=2$, hence $\mathrm{m}=2$ and $\mathrm{n}=1$

- For coal, $\mathrm{m} / \mathrm{n}=1$, hence $\mathrm{m}=1$ and $\mathrm{n}=1$.

Gasification temperatures are so high that, thermodynamically as well as in practice, no hydrocarbons other than methane can be present in any appreciable quantity.

Thermodynamic equilibrium: As an example: Equations (1) and (5) produce $\mathrm{H}_{2}$ and $\mathrm{CO}$ which absorbs and releases heat

$$
\begin{aligned}
& \mathrm{C}+1 / 2 \mathrm{O}_{2}=\mathrm{CO}-111 \mathrm{MJ} / \mathrm{kmol}(10) \\
& \mathrm{C}+\mathrm{H}_{2} \mathrm{O}=\mathrm{CO}+\mathrm{H}_{2}+131 \mathrm{MJ} / \mathrm{kmol}(11)
\end{aligned}
$$

The molar weight and mass flow rate ton/day (TPD) of each component in both sides of Eqs. (10) and (11) can be determined and written under each equation for clarity.

Equation (10) releases heat, and Eq. (11) absorbs heat. The heat released is used to heat a fire tube boiler or utilized in another gasification application.

The above methodology is used in what follows to conduct detailed calculations of the syngas composition, cold gas efficiency, and carbon conversion efficiency, but for one coal type, bituminous coal, which is the mostly used in power plants. The purpose of this is to show the step by step of such calculation procedures. This is done for the three studied gasification processes. The results for other coals are given briefly following the same procedures as in the case of bituminous coal.

\begin{tabular}{|c|c|c|c|c|c|c|c|}
\hline$\%$ Coal type & C & $\mathbf{H}$ & $\mathbf{0}$ & $\mathbf{N}$ & $S$ & Moisture & Ash \\
\hline Anthracite & 76.1 & 1.8 & 1.8 & 0.6 & 0.6 & 5.4 & 13.7 \\
\hline Bituminous & 80.7 & 4.5 & 2.4 & 1.1 & 1.8 & 3.3 & 6.2 \\
\hline Sub bituminous & 58.8 & 3.8 & 12.2 & 1.3 & 0.3 & 19.6 & 4 \\
\hline Lignite & 42.4 & 2.8 & 12.4 & 0.7 & 0.7 & 34.8 & 6.2 \\
\hline
\end{tabular}

\section{Data and Assumptions}

To perform the calculations, numerical data and assumptions should be made. The coal ranks considered cover the high grade ones (anthracite and bituminous) and low ranks (sub-bituminous and lignite). Mass percentages of constituents of coals are depicted in Table 1 [5].

Table 1: Coal compositions at combustion.

To get coal chemical compositions, we must calculate mole fractions of all species and hence their normalized values with respect to carbon, and these are presented in Table 2. Coal compositions as extracted from the normalized mole fractions, in
Table 2, are shown in Table 3.

Equations for complete combustion of coals are indicated in Table 4. 
Table 2: Mole fractions and normalized values with respect to carbon of coal constituents.

\begin{tabular}{|c|c|c|c|c|c|}
\hline \multirow{2}{*}{ Coal } & \multicolumn{5}{|c|}{ Mole fraction and normalized values in ( ) } \\
\hline & C & H & $\mathbf{0}$ & $\mathbf{N}$ & $\mathbf{S}$ \\
\hline Anthracite & $\begin{array}{c}6.3416 \\
(1)\end{array}$ & $\begin{array}{c}1.8 \\
(0.2838)\end{array}$ & $\begin{array}{c}0.1125 \\
(0.0067)\end{array}$ & $\begin{array}{c}0.0428 \\
(0.0067)\end{array}$ & $\begin{array}{c}0.0187 \\
(0.0029)\end{array}$ \\
\hline Bituminous & $\begin{array}{c}6.725 \\
(1)\end{array}$ & $\begin{array}{c}4.5 \\
(0.6691)\end{array}$ & $\begin{array}{c}0.15 \\
(0.0223)\end{array}$ & $\begin{array}{c}0.0785 \\
(0.0116)\end{array}$ & $\begin{array}{c}0,0562 \\
(0.0083)\end{array}$ \\
\hline Sub- bituminous & $\begin{array}{l}4.9 \\
(1)\end{array}$ & $\begin{array}{c}3.8 \\
(0.7755)\end{array}$ & $\begin{array}{c}0.7625 \\
(0.1566)\end{array}$ & $\begin{array}{c}0.0928 \\
(0.0189)\end{array}$ & $\begin{array}{c}0.0093 \\
(0.0019)\end{array}$ \\
\hline Lignite & $\begin{array}{c}3.533 \\
(1)\end{array}$ & $\begin{array}{c}2.8 \\
(0.7825)\end{array}$ & $\begin{array}{c}0.775 \\
(0.2193)\end{array}$ & $\begin{array}{c}0.05 \\
(0.0141)\end{array}$ & $\begin{array}{c}0.0218 \\
(0.0061)\end{array}$ \\
\hline
\end{tabular}

Note: Molar fractions are estimated by dividing the mass percentage of each species (from Table 1) by its atomic weight. Example: for bituminous coal, the mole fraction of $\mathrm{C}=76.1 / 12=6.6735, \mathrm{H}=4.5 / 1=4.5, \mathrm{~S}=1.8 / 32=0.0083$. Normalized values are obtained by dividing the mole fraction of the species by that of carbon. For example: for bituminous coal, $\mathrm{C}=7.625 / 7.625=1$, and $\mathrm{N}=0.0785 / 7.625=$ 0.0116 .

Table 3: Chemical compositions of coal ranks. Note: coal compositions are extracted from the normalized values given in Table 2.

\begin{tabular}{|c|c|}
\hline Coal & Composition \\
\hline Anthracite & $\mathrm{C} \mathrm{H}_{0.28} \mathrm{O}_{0.0177} 7 \mathrm{~N}_{0.0067} \mathrm{~S}_{0.0029}$ \\
\hline Bituminous & $\mathrm{C} \mathrm{H}_{0.67} \mathrm{O}_{0.022} \mathrm{~N}_{0.0116} \mathrm{~S}_{0.008}$ \\
\hline Sub- bituminous & $\mathrm{C} \mathrm{H}_{0.775} \mathrm{O}_{0.155} \mathrm{~N}_{0.0189} \mathrm{~S}_{0.0019}$ \\
\hline Lignite & $\mathrm{C} \mathrm{H}_{0.8} \mathrm{O}_{0.22} \mathrm{~N}_{0.014} \mathrm{~S}_{0.006}$ \\
\hline
\end{tabular}

Table 4: Equations for complete combustion of coals.

\begin{tabular}{|c|c|}
\hline Coal & Complete combustion equation \\
\hline Anthracite & $\mathrm{C} \mathrm{H}_{0.28} \mathrm{O}_{0.0177} \mathrm{~N}_{0.0067} \mathrm{~S}_{0.0029}+1.064\left(\mathrm{O}_{2}+3.78 \mathrm{~N}_{2}\right)=\mathrm{CO}_{2}+0.14 \mathrm{H}_{2} \mathrm{O}+0.0029 \mathrm{SO}_{2}+4.025 \mathrm{~N}_{2}$ \\
\hline Bituminous & $\mathrm{CH}_{0.67} \mathrm{O}_{0.022} \mathrm{~N}_{0.0116} \mathrm{~S}_{0.008}+1.1645\left(\mathrm{O}_{2}+3.78 \mathrm{~N}_{2}\right)=\mathrm{CO}_{2}+0.335 \mathrm{H}_{2} \mathrm{O}+0.008 \mathrm{SO}_{2}+4.4 \mathrm{~N}_{2}$ \\
\hline Sub- bituminous & $\mathrm{CH}_{0.775} \mathrm{O}_{0.155} \mathrm{~N}_{0.0189} \mathrm{~S}_{0.0019}+1.118\left(\mathrm{O}_{2}+3.78 \mathrm{~N}_{2}\right)=\mathrm{CO}_{2}+0.3875 \mathrm{H}_{2} \mathrm{O}+0.0019 \mathrm{SO}_{2}+4.235 \mathrm{~N}_{2}$ \\
\hline Lignite & $\mathrm{CH}_{0.8} \mathrm{O}_{0.22} \mathrm{~N}_{0.014} \mathrm{~S}_{0.006}+1.096\left(\mathrm{O}_{2}+3.78 \mathrm{~N}_{2}\right)=\mathrm{CO}_{2}+0.4 \mathrm{H}_{2}+0.006 \mathrm{SO}_{2}+4.15 \mathrm{~N}_{2}$ \\
\hline
\end{tabular}

The heating values used in calculations of cold gas efficiencies are listed in Table 5.

Table 5: Heating values of coals and gases.

\begin{tabular}{|c|c|}
\hline Species & Heating values (kJ/kg) \\
\hline Anthracite coal & 33300 (HHV) \\
\hline Bituminous coal & $27800(\mathrm{HHV})$ \\
\hline Sub- bituminous coal & $23600(\mathrm{HHV})$ \\
\hline Lignite coal & $16800(\mathrm{HHV})$ \\
\hline $\mathrm{H}_{2}$ & $121000(\mathrm{LHV})$ \\
\hline $\mathrm{CO}$ & $10095(\mathrm{LHV})$ \\
\hline $\mathrm{CH}_{4}$ & $49995(\mathrm{LHV})$ \\
\hline
\end{tabular}

Note: HHV= High Heating Value, and LHV= Low Heating Value.

For all present calculations, we assumed a flow rate of coal in gasifiers $=2500 \mathrm{TPD}$. Oxygen is blown in gasifiers and the pressure $=$ $30 \mathrm{~atm}$.

The chemical equation in gasifiers is

$\mathrm{CH}_{0.67} \mathrm{O}_{0.022} \mathrm{~N}_{0.0116} \mathrm{~S}_{0.008^{*}}+\mathrm{a} \mathrm{H}_{2} \mathrm{O}+\mathrm{b} \mathrm{O}_{2}=\mathrm{e} \mathrm{CO}+\mathrm{f} \mathrm{H}_{2}+\mathrm{g} \mathrm{COS}+\mathrm{j} \mathrm{H}_{2} \mathrm{~S}$ $+\mathrm{kCO}_{2}+\mathrm{lCH}_{4}+\mathrm{m} \mathrm{H}_{2} \mathrm{O}$

Where: $a, b, c . . . . e t c$ are fractions determined for each coal and each gasifier.

\section{Detailed Calculations for Bituminous Coal}

In the following calculations the molar weight of carbon in coal $M_{c}=100 / 6.725=14.869 \mathrm{gm} / \mathrm{mole}$. From the mass weights in Table 1 , moisture and ash flow rates are $82.5(=0.033 \times 2500)$ and 155 TPD (=0.062x 2500$)$, respectively. 


\section{Entrained Flow Gasification}

Reactions in gasifier:

\section{A. Pyrolysis and devolatilization of coal}

$\mathrm{C}_{\mathrm{s}}=0.3345 \mathrm{H}_{2}+0272 \mathrm{H}_{2} \mathrm{O}+0.0058 \mathrm{~N}_{2}+0.008 \mathrm{H}_{2} \mathrm{~S}+0.0115 \mathrm{O}_{2}$ (12)

14.8690 .6690 .48960 .16240 .2720 .3568

2500 TPD 112.582 .527 .547 .81260

$\mathrm{H}_{2}+\mathrm{S}=\mathrm{H}_{2} \mathrm{~S}(13)$

23234

2.812 TPD 4547.812

\section{B. Gasification}

$3 \mathrm{C}_{\mathrm{s}}+\mathrm{H}_{2} \mathrm{O}+\mathrm{O}_{2}=3 \mathrm{CO}+\mathrm{H}_{2}(14)$

44.6071832842

2500 TPD 1008.811793 .444707 .781112 .09

\section{Combustion}

$\mathrm{CO}+0.5 \mathrm{O}_{2}=\mathrm{CO}_{2}(15)$

281644

\subsection{TPD 306.56843 .04}

\section{Water from partial combustion}

$\mathrm{H}_{2}+0.5 \mathrm{O}_{2}=\mathrm{H}_{2} \mathrm{O}$ (Water with slag) (16)

21618

\subsection{TPD 6067.5}

From above calculations, $\dot{\mathrm{m}}_{02}=2100$ TPD (= $84 \%$ by weight of coal), and $\dot{\mathrm{m}}_{\mathrm{CO}}=1008.81 \mathrm{TPD}(=40.352 \%$ of slurry feed $)$

a) Mass flow rates of gasses in syngas $\left(\dot{\mathrm{m}}_{\mathrm{gas}}\right) \mathrm{TPD}$ 47.812

$\dot{\mathrm{m}}_{\mathrm{CO2}}=843.04 \dot{\mathrm{m}}_{\mathrm{CO}}=4171.301 \dot{\mathrm{m}}_{\mathrm{H} 2}=214.278 \dot{\mathrm{m}}_{\mathrm{N} 2}=27.5 \dot{\mathrm{m}}_{\mathrm{H} 2 \mathrm{~S}}=$

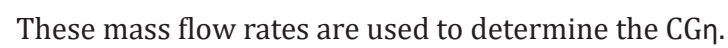

$\mathrm{CH}_{0.67} \mathrm{O}_{0.022} \mathrm{~N}_{0.0116} \mathrm{~S}_{0.008^{*}}+0.333 \mathrm{H}_{2} \mathrm{O}+0.39 \mathrm{O}_{2}=0.886 \mathrm{CO}+0.637$ $\mathrm{H}_{2}+0.008 \mathrm{H}_{2} \mathrm{~S}+0.114 \mathrm{CO}_{2}+0.006 \mathrm{~N}_{2}+0.022 \mathrm{H}_{2} \mathrm{O}(17)$

Total moles of syngas $=\Sigma$ fractions in the RHS of Eq. $(17)=1.673$

$\mathrm{Y}_{\text {gas }}(\%)=$ (number of moles in species / total moles in syngas $)$ $\mathrm{x} 100$

$\mathrm{Y}_{\mathrm{CO} 2}=6.814 \mathrm{Y}_{\mathrm{CO}}=52.958 \mathrm{Y}_{\mathrm{H} 2}=38.075 \mathrm{Y}_{\mathrm{N} 2}=0.358 \mathrm{Y}_{\mathrm{H} 2 \mathrm{~S}}=0.478$

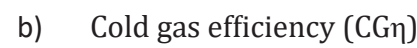

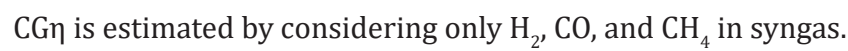

$\Delta \mathrm{H}_{\mathrm{C}}=300088.4\{=(214.278 \times 1000 / 24 \times 60 \times 60) \times 121000\}+$ $487375.97=787464.37 \mathrm{~kW}$
$\mathrm{CG \eta}=\left[\Delta \mathrm{Hc} /\left(\dot{\mathrm{m}}_{\mathrm{c}}(=2500 \mathrm{TPD}) \times \mathrm{HHV}\right)_{\text {Coal }}\right] \times 100=[787464.3 /$ $963541.67[=\{(2500 \times 1000 / 24 \times 60 \times 60) \times 333000\}] \times 100=81.726$ $\%$

c) Carbon conversion efficiency $(\mathrm{CC} \eta)$

$\mathrm{CC} \eta=\dot{\mathrm{m}}$ carbon in coal $/ \dot{\mathrm{m}}$ carbon in syngas $=[(2500 / 2500)$ $\times 100=100 \%$

\section{Fluidized Bed Gasification}

Reactions in gasifier:

A. Pyrolysis and devolatilization: Equation (12) still applies.

B. Gasification and combustion

$3 \mathrm{C}_{\mathrm{S}}+\mathrm{H}_{2} \mathrm{O}+\mathrm{O}_{2}=3 \mathrm{CO}+\mathrm{H}_{2}(18)$

44.6071832842

2265.2 TPD 914.06216254265 .625101 .562

C. Water from partial combustion: Equation (16) is the same.

D. Water gas shift

$\mathrm{CO}+\mathrm{H}_{2} \mathrm{O}=\mathrm{CO}_{2}+\mathrm{H}_{2}(19)$

2818442

911.459 TPD 585.9381432 .29365 .104

E. Methanation

$\mathrm{C}_{\mathrm{S}}+2 \mathrm{H}_{2}=\mathrm{CH}_{4}(20)$

14.869416

159.8 TPD 42.988171 .955

The above results reveal that $\dot{\mathrm{m}}_{02}$ and $\dot{\mathrm{m}}_{\text {steam }}$ (steam feed) are 1750 and 1500 TPD, i.e. 70 and $60 \%$ by weight of coal, respectively.

a) $\dot{\mathrm{m}}_{\text {gas }}(\mathrm{TPD})$

$\dot{\mathrm{m}}_{\mathrm{CO2}}=1432.293 \dot{\mathrm{m}}_{\mathrm{CO}}=3354.166 \dot{\mathrm{m}}_{\mathrm{H} 2}=228.678 \dot{\mathrm{m}}_{\mathrm{N} 2}=27.5 \dot{\mathrm{m}}_{\mathrm{CH} 4}=$ $171.955 \dot{\mathrm{m}}_{\text {Steam }}=82.5$

$\mathrm{CH}_{0.67} \mathrm{O}_{0.022} \mathrm{~N}_{0.0116} \mathrm{~S}_{0.008}+0.495 \mathrm{H}_{2} \mathrm{O}+0.302 \mathrm{O}_{2}=0.712 \mathrm{CO}+0.68$ $\mathrm{H}_{2}+0.064 \mathrm{CH}_{4}+0.193 \mathrm{CO}_{2}+0.027 \mathrm{H}_{2} \mathrm{O}+0.006 \mathrm{~N}_{2}(21)$

$\mathrm{Y}_{\text {gas }}(\%)$ :

Total moles of syngas $=1.682$

$\mathrm{Y}_{\mathrm{CO} 2}=11.474 \mathrm{Y}_{\mathrm{CO}}=42.33 \mathrm{Y}_{\mathrm{H} 2}=40.428 \mathrm{Y}_{\mathrm{CH} 4}=3.805 \mathrm{Y}_{\mathrm{N} 2}=0.356$ $\mathrm{Y}_{\mathrm{H} 2 \mathrm{~S}}=0 \mathrm{Y}_{\text {Steam }}=1.605$

b) $\mathrm{CG \eta}$

$\Delta \mathrm{H}_{\mathrm{C}}=320255.07+391901.69+99501.044=811657.8 \mathrm{~kW}$

$-\mathrm{CG \eta}=\left[\Delta \mathrm{H}_{\mathrm{C}} /(\dot{\mathrm{m}} \times \mathrm{HHV})_{\text {Coal }}\right] \times 100=[811657.8 / 963541.67]$ $\times 100=84.237 \%$

c) $\mathrm{CC} \eta$

$\mathrm{CC} \eta==[2425 / 2500] \times 100=97 \%$ 


\section{Fixed Bed Gasification}

Reactions in gasifier:

A. Pyrolysis and devolatilization: Equations (12) and (13) are applicable.

B. Gasification and combustion

$3 \mathrm{C}_{\mathrm{S}}+\mathrm{H}_{2} \mathrm{O}+\mathrm{O}_{2}=3 \mathrm{CO}+\mathrm{H}_{2}(22)$

44.6071832842

1847.008 TPD 745.31213253478.12582.812

C. Water from partial combustion: Equation (16) applies

D. Steam Gasification

$\mathrm{C}_{\mathrm{S}}+2 \mathrm{H}_{2} \mathrm{O}=\mathrm{CO}_{2}+2 \mathrm{H}_{2}(23)$

14.86936444

105.193 TPD 254.688 311.285 28.298

E. Direct methanation

$\mathrm{C}_{\mathrm{S}}+2 \mathrm{H}_{2}=\mathrm{CH}_{4}(24)$

14.869416

\subsection{TPD 133.916535 .663}

Here $\dot{\mathrm{m}}_{\mathrm{O} 2}$ and $\dot{\mathrm{m}}_{\text {steam }}$ (steam feed) are 1325 and 1000 TPD, i.e. 53 and $40 \%$ by weight of coal, respectively.

a) $\dot{\mathrm{m}}_{\text {gas }}(\mathrm{TPD})$

$\dot{\mathrm{m}}_{\mathrm{CO} 2}=311.285 \dot{\mathrm{m}}_{\mathrm{CO}}=3478.125 \dot{\mathrm{m}}_{\mathrm{H} 2}=79.38 \dot{\mathrm{m}}_{\mathrm{N} 2}=27.5 \dot{\mathrm{m}}_{\mathrm{CH} 4}=$ $535.663 \dot{\mathrm{m}}_{\mathrm{H} 2}=47.812 \dot{\mathrm{m}}_{\text {Steam }}=82.5$

$\mathrm{CH}_{0.67} \mathrm{O}_{0.022} \mathrm{~N}_{0.0116} \mathrm{~S}_{0.008 .}+0.33 \mathrm{H}_{2} \mathrm{O}+0.246 \mathrm{O}_{2}=0.739 \mathrm{CO}+0.236$ $\mathrm{H}_{2}+0.199 \mathrm{CH}_{4}+0.008 \mathrm{H}_{2} \mathrm{~S}+0.042 \mathrm{CO}_{2}+0.006 \mathrm{~N}_{2}+0.027 \mathrm{H}_{2} \mathrm{O}(25)$

$\mathrm{Y}_{\text {gas }}(\%)$ :

Total moles of syngas $=1.257$

$\mathrm{Y}_{\mathrm{CO} 2}=3.341 \mathrm{Y}_{\mathrm{CO}}=58.79 \mathrm{Y}_{\mathrm{H} 2}=18.775 \mathrm{Y}_{\mathrm{CH} 4}=15.831 \mathrm{Y}_{\mathrm{N} 2}=0.477$ $\mathrm{Y}_{\mathrm{H} 2 \mathrm{~S}}=0.636 \mathrm{Y}_{\mathrm{H} 2 \mathrm{O}}=2.148$

b) $\mathrm{CG \eta}$

$\Delta \mathrm{H}_{\mathrm{C}}=111171.55+406384.51+309959.16=827515.22 \mathrm{~kW}$

$\mathrm{CG \eta}=\left[\Delta \mathrm{H}_{\mathrm{C}} /(\dot{\mathrm{m}} \times \mathrm{HHV})_{\text {Coal }}\right] \times 100=[827515.22 / 963541.67]$ $\times 100=85.882 \%$

c) $\mathrm{CC} \eta$

$\mathrm{CC} \eta==[2450 / 2500] \times 100=98 \%$

\section{Calculations for Other Coals}

\section{Entrained Flow Gasification}

\section{Anthracite coal}

Mass flow rate of oxygen blown in gasifier $\left(\dot{\mathrm{m}}_{\mathrm{0} 2}\right)=1980.297$ TPD
Mass flow rate of water slurry $\left(\dot{\mathrm{m}}_{\text {water }}\right)=951.25 \mathrm{TPD}$

$\dot{\mathrm{m}}_{\text {gas }}$ (TPD):

$\dot{\mathrm{m}}_{\mathrm{CO} 2}=795.262 \dot{\mathrm{m}}_{\mathrm{CO}}=3933.091 \dot{\mathrm{m}}_{\mathrm{H} 2}=144.132 \dot{\mathrm{m}}_{\mathrm{N} 2}=15 \dot{\mathrm{m}}_{\mathrm{H} 2 \mathrm{~S}}=$ $15.938 \dot{\mathrm{m}}_{\text {Steam }}=135$

Chemical equation:

$\mathrm{CH}_{0.28} \mathrm{O}_{0.0177} \mathrm{~N}_{0.0067} \mathrm{~S}_{0.0029}+0.333 \mathrm{H}_{2} \mathrm{O}+0.39 \mathrm{O}_{2}=0.886 \mathrm{CO}+$ $0.454 \mathrm{H}_{2}+0.003 \mathrm{H}_{2} \mathrm{~S}+0.114 \mathrm{CO}_{2}+0.003 \mathrm{~N}_{2}+0.047 \mathrm{H}_{2} \mathrm{O}(26)$

a) $Y_{\text {gas }}(\%)$ :

All moles of syngas $=1.507$

$\mathrm{Y}_{\mathrm{CO} 2}=7.564 \mathrm{Y}_{\mathrm{CO}}=58.792 \mathrm{Y}_{\mathrm{H} 2}=30.126 \mathrm{Y}_{\mathrm{N} 2}=0.2 \mathrm{Y}_{\mathrm{H} 2 \mathrm{~S}}=0.2 \mathrm{Y}_{\mathrm{H} 2 \mathrm{O}}=3.118$

\section{Sub bituminous coal:}

$$
\begin{aligned}
& \dot{\mathrm{m}}_{\mathrm{O} 2}=1530.112 \mathrm{TPD} \\
& \dot{\mathrm{m}}_{\text {water }}=735 \mathrm{TPD} \\
& \dot{\mathrm{m}}_{\mathrm{gas}} \text { (TPD): } \\
& \dot{\mathrm{m}}_{\mathrm{CO2}}=614.473 \dot{\mathrm{m}}_{\mathrm{CO}}=3038.971 \dot{\mathrm{m}}_{\mathrm{H} 2}=138.073 \dot{\mathrm{m}}_{\mathrm{N} 2}=32.5 \dot{\mathrm{m}}_{\mathrm{H} 2 \mathrm{~S}}=
\end{aligned}
$$
$7.969 \dot{\mathrm{m}}_{\text {Steam }}=490$

a) Chemical equation:

$\mathrm{C} \mathrm{H}_{0.775} \mathrm{O}_{0.155} \mathrm{~N}_{0.0189} \mathrm{~S}_{0.0019}+0.333 \mathrm{H}_{2} \mathrm{O}+0.39 \mathrm{O}_{2}=0.886 \mathrm{CO}+$ $0.563 \mathrm{H}_{2}+0.002 \mathrm{H}_{2} \mathrm{~S}+0.114 \mathrm{CO}_{2}+0.01 \mathrm{~N}_{2}+0.222 \mathrm{H}_{2} \mathrm{O}$ (27)

Total moles of syngas $=1.797$

$$
\mathrm{Y}_{\mathrm{CO} 2}=6.344 \mathrm{Y}_{\mathrm{CO}}=49.304 \mathrm{Y}_{\mathrm{H} 2}=31.33 \mathrm{Y}_{\mathrm{N} 2}=0.556 \mathrm{Y}_{\mathrm{H} 2 \mathrm{~S}}=0.111 \mathrm{Y}_{\mathrm{H} 2 \mathrm{O}}=
$$
12.354

\section{Lignite coal:}

$$
\begin{aligned}
& \dot{\mathrm{m}}_{\mathrm{O} 2}=1103.346 \mathrm{TPD} \\
& \dot{\mathrm{m}}_{\text {water }}=530 \mathrm{TPD} \\
& \dot{\mathrm{m}}_{\mathrm{gas}(\mathrm{TPD})}: \\
& \dot{\mathrm{m}}_{\mathrm{CO2}}=443.09 \dot{\mathrm{m}}_{\mathrm{CO}}=2191.367 \dot{\mathrm{m}}_{\mathrm{H} 2}=89.045 \dot{\mathrm{m}}_{\mathrm{N} 2}=17.5 \dot{\mathrm{m}}_{\mathrm{H} 2 \mathrm{~S}}=
\end{aligned}
$$
$18.594 \dot{\mathrm{m}}_{\text {Steam }}=870$
a) Chemical equation:

$\mathrm{C} \mathrm{H}_{0.8} \mathrm{O}_{0.22} \mathrm{~N}_{0.014} \mathrm{~S}_{0.006}+0.333 \mathrm{H}_{2} \mathrm{O}+0.39 \mathrm{O}_{2}=0.886 \mathrm{CO}+0.504 \mathrm{H}_{2}$ $+0.006 \mathrm{H}_{2} \mathrm{~S}+0.114 \mathrm{CO}_{2}+0.007 \mathrm{~N}_{2}+0.547 \mathrm{H}_{2} \mathrm{O}(28)$

b) $\mathrm{Y}_{\text {gas }}(\%)$ :

Total moles of syngas $=2.064$

$\mathrm{Y}_{\mathrm{CO} 2}=5.523 \mathrm{Y}_{\mathrm{CO}}=42.926 \mathrm{Y}_{\mathrm{H} 2}=24.418 \mathrm{Y}_{\mathrm{N} 2}=0.339 \mathrm{Y}_{\mathrm{H} 2 \mathrm{~S}}=0.29 \mathrm{Y}_{\mathrm{H} 2 \mathrm{O}}=$ 26.502

\section{Fluidized Bed Gasification}

\section{Anthracite coal:}

$$
\left(\dot{\mathrm{m}}_{\mathrm{O} 2}\right)=1650.248 \mathrm{TPD}
$$




$$
\begin{aligned}
& \left(\dot{\mathrm{m}}_{\text {water }}\right)=1414.498 \mathrm{TPD} \\
& \dot{\mathrm{m}}_{\mathrm{gas}}(\mathrm{TPD}): \\
& \dot{\mathrm{m}}_{\mathrm{CO2}}=1350.649 \dot{\mathrm{m}}_{\mathrm{CO}}=3162.975 \dot{\mathrm{m}}_{\mathrm{H} 2}=156.040 \dot{\mathrm{m}}_{\mathrm{N} 2}=15 \dot{\mathrm{m}}_{\mathrm{CH} 4}= \\
& 162.007 \dot{\mathrm{m}}_{\text {Steam }}=135
\end{aligned}
$$

a) Chemical equation:

$\mathrm{C} \mathrm{H}_{0.28} \mathrm{O}_{0.0177} \mathrm{~N}_{0.0067} \mathrm{~S}_{0.0029}+0.495 \mathrm{H}_{2} \mathrm{O}+0.325 \mathrm{O}_{2}=0.712 \mathrm{CO}+$ $0.492 \mathrm{H}_{2}+0.064 \mathrm{CH}_{4}+0.193 \mathrm{CO}_{2}+0.003 \mathrm{~N}_{2}+0.047 \mathrm{H}_{2} \mathrm{O}$ (29)

b) $\mathrm{Y}_{\text {gas }}(\%)$ :

Total moles of syngas $=1.511$

$\mathrm{Y}_{\mathrm{CO} 2}=12.773 \mathrm{Y}_{\mathrm{CO}}=47.121 \mathrm{Y}_{\mathrm{H} 2}=32.561 \mathrm{Y}_{\mathrm{N} 2}=0.198 \mathrm{Y}_{\mathrm{CH} 4}=4.235$ $\mathrm{Y}_{\mathrm{H} 2 \mathrm{O}}=3.11$

\section{Sub bituminous coal:}

$\dot{\mathrm{m}}_{02}=1275.093 \mathrm{TPD}$

Mass flow rate of steam for gasification $\left(\dot{\mathrm{m}}_{\text {steam }}\right)=1092 \mathrm{TPD}$

$\dot{\mathrm{m}}_{\text {gas }}(\mathrm{TPD})$ :

$\dot{\mathrm{m}}_{\mathrm{CO} 2}=1043.603 \dot{\mathrm{m}}_{\mathrm{CO}}=2443.928 \dot{\mathrm{m}}_{\mathrm{H} 2}=147.018 \dot{\mathrm{m}}_{\mathrm{N} 2}=32.5 \dot{\mathrm{m}}_{\mathrm{CH} 4}=$ $125.178 \dot{\mathrm{m}}_{\text {Steam }}=490$

a) Chemical equation:

$\mathrm{CH}_{0.775} \mathrm{O}_{0.155} \mathrm{~N}_{0.0189} \mathrm{~S}_{0.0019}+0.495 \mathrm{H}_{2} \mathrm{O}+0.325 \mathrm{O}_{2}=0.712 \mathrm{CO}+0.6$ $\mathrm{H}_{2}+0.064 \mathrm{CH}_{4}+0.193 \mathrm{CO}_{2}+0.01 \mathrm{~N}_{2}+0.222 \mathrm{H}_{2} \mathrm{O}(30)$

b) $\mathrm{Y}_{\text {gas }}(\%)$ :

Total moles of syngas $=1.801$

$\mathrm{Y}_{\mathrm{CO} 2}=10.716 \mathrm{Y}_{\mathrm{CO}}=39.533 \mathrm{Y}_{\mathrm{H} 2}=33.314 \mathrm{Y}_{\mathrm{N} 2}=0.555 \mathrm{Y}_{\mathrm{CH} 4}=3.553$ $\mathrm{Y}_{\mathrm{H} 2 \mathrm{O}}=12.326$

\section{Lignite coal:}

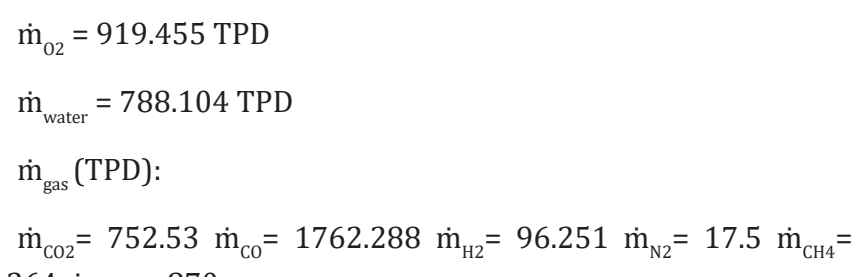
$90.264 \dot{\mathrm{m}}_{\text {Steam }}=870$

a) Chemical equation:

$\mathrm{CH}_{0.8} \mathrm{O}_{0.22} \mathrm{~N}_{0.014} \mathrm{~S}_{0.006}+0.495 \mathrm{H}_{2} \mathrm{O}+0.325 \mathrm{O}_{2}=0.712 \mathrm{CO}+0.544$ $\mathrm{H}_{2}+0.064 \mathrm{CH}_{4}+0.193 \mathrm{CO}_{2}+0.007 \mathrm{~N}_{2}+0.547 \mathrm{H}_{2} \mathrm{O}$ (31)

b) $\mathrm{Y}_{\text {gas }}(\%)$ :

Total of moles of syngas $=2.067$

$\mathrm{Y}_{\mathrm{CO} 2}=9.337 \mathrm{Y}_{\mathrm{CO}}=34.446 \mathrm{Y}_{\mathrm{H} 2}=26.318 \mathrm{Y}_{\mathrm{N} 2}=0.338 \mathrm{Y}_{\mathrm{CH} 4}=3.096$ $\mathrm{Y}_{\mathrm{H} 2 \mathrm{O}}=26.463$

\section{Fixed Bed Gasification}

\section{Anthracite coal:}

$$
\begin{aligned}
& \dot{\mathrm{m}}_{\mathrm{O} 2}=1249.473 \mathrm{TPD} \\
& \dot{\mathrm{m}}_{\text {steam }}=942.999 \mathrm{TPD} \\
& \dot{\mathrm{m}}_{\mathrm{gas}}(\mathrm{TPD}): \\
& \dot{\mathrm{m}}_{\mathrm{CO2}}=293.541 \dot{\mathrm{m}}_{\mathrm{CO}}=3279.868 \dot{\mathrm{m}}_{\mathrm{H} 2}=16.97 \dot{\mathrm{m}}_{\mathrm{N} 2}=15 \dot{\mathrm{m}}_{\mathrm{CH} 4}=
\end{aligned}
$$
$504.981 \dot{\mathrm{m}}_{\text {Steam }}=135 \dot{\mathrm{m}}_{\mathrm{H} 2 \mathrm{~S}}=15.938$

a) Chemical equation:

$\mathrm{CH}_{0.28} \mathrm{O}_{0.0177} \mathrm{~N}_{0.0067} \mathrm{~S}_{0.0029}+0.33 \mathrm{H}_{2} \mathrm{O}+0.246 \mathrm{O}_{2}=0.739 \mathrm{CO}+0.053$ $\mathrm{H}_{2}+0.199 \mathrm{CH}_{4}+0.042 \mathrm{CO}_{2}+0.003 \mathrm{~N}_{2}+0.047 \mathrm{H}_{2} \mathrm{O}+0.003 \mathrm{H}_{2} \mathrm{~S}(32)$

b) $\mathrm{Y}_{\text {gas }}(\%)$ :

Total moles of syngas $=1.086$

$\mathrm{Y}_{\mathrm{CO} 2}=3.867 \mathrm{Y}_{\mathrm{CO}}=68.047 \mathrm{Y}_{\mathrm{H} 2}=4.88 \mathrm{Y}_{\mathrm{N} 2}=0.276 \mathrm{Y}_{\mathrm{CH} 4}=18.324 \mathrm{Y}_{\mathrm{H} 2 \mathrm{O}}=$ $4.327 \mathrm{Y}_{\mathrm{H} 2 \mathrm{~S}}=0.276$

\section{Sub bituminous coal:}

$$
\begin{aligned}
& \dot{\mathrm{m}}_{\mathrm{O} 2}=965.427 \text { TPD } \\
& \dot{\mathrm{m}}_{\text {steam }}=728.624 \text { TPD }
\end{aligned}
$$

$\dot{\mathrm{m}}_{\text {gas }}(\mathrm{TPD})$ :

$\dot{\mathrm{m}}_{\mathrm{CO} 2}=226.81 \dot{\mathrm{m}}_{\mathrm{CO}}=2534.247 \dot{\mathrm{m}}_{\mathrm{H} 2}=39.819 \dot{\mathrm{m}}_{\mathrm{N} 2}=32.5 \dot{\mathrm{m}}_{\mathrm{CH} 4}=$ $390.183 \dot{\mathrm{m}}_{\text {Steam }}=490 \dot{\mathrm{m}}_{\mathrm{H} 2 \mathrm{~S}}=7.969$
a) Chemical equation:

$\mathrm{CH}_{0.775} \mathrm{O}_{0.155} \mathrm{~N}_{0.0189} \mathrm{~S}_{0.0019}+0.33 \mathrm{H}_{2} \mathrm{O}+0.246 \mathrm{O}_{2}=0.739 \mathrm{CO}+0.162$ $\mathrm{H}_{2}+0.199 \mathrm{CH}_{4}+0.042 \mathrm{CO}_{2}+0.01 \mathrm{~N}_{2}+0.222 \mathrm{H}_{2} \mathrm{O}+0.002 \mathrm{H}_{2} \mathrm{~S}(33)$

b) $\mathrm{Y}_{\mathrm{gas}}(\%)$ :

Total moles of syngas $=1.376$

$\mathrm{Y}_{\mathrm{CO} 2}=3.052 \mathrm{Y}_{\mathrm{CO}}=53.706 \mathrm{Y}_{\mathrm{H} 2}=11.773 \mathrm{Y}_{\mathrm{N} 2}=0.726 \mathrm{Y}_{\mathrm{CH} 4}=14.462$ $\mathrm{Y}_{\mathrm{H} 2 \mathrm{O}}=16.133 \mathrm{Y}_{\mathrm{H} 2 \mathrm{~S}}=0.145$

Lignite coal:

$\dot{\mathrm{m}}_{\mathrm{O} 2}=696.159 \mathrm{TPD}$

$\dot{\mathrm{m}}_{\text {steam }}=525.403 \mathrm{TPD}$

$\dot{\mathrm{m}}_{\text {gas }}(\mathrm{TPD})$ :

$\dot{\mathrm{m}}_{\mathrm{CO} 2}=163.55 \dot{\mathrm{m}}_{\mathrm{CO}}=1827.416 \dot{\mathrm{m}}_{\mathrm{H} 2}=18.195 \dot{\mathrm{m}}_{\mathrm{N} 2}=17.5 \dot{\mathrm{m}}_{\mathrm{CH} 4}=$ $281.356 \dot{\mathrm{m}}_{\text {Steam }}=870 \dot{\mathrm{m}}_{\mathrm{H} 2 \mathrm{~S}}=18.594$

a) Chemical equation:

$\mathrm{CH}_{0.8} \mathrm{O}_{0.22} \mathrm{~N}_{0.014} \mathrm{~S}_{0.006}+0.33 \mathrm{H}_{2} \mathrm{O}+0.246 \mathrm{O}_{2}=0.739 \mathrm{CO}+0.103$ $\mathrm{H}_{2}+0.199 \mathrm{CH}_{4}+0.042 \mathrm{CO}_{2}+0.007 \mathrm{~N}_{2}+0.547 \mathrm{H}_{2} \mathrm{O}+0.006 \mathrm{H}_{2} \mathrm{~S}(34)$

b) $\mathrm{Y}_{\text {gas }}(\%)$ : 
Total moles of syngas $=1.643$

$\mathrm{Y}_{\mathrm{CO} 2}=2.556 \mathrm{Y}_{\mathrm{CO}}=44.978 \mathrm{Y}_{\mathrm{H} 2}=6.269 \mathrm{Y}_{\mathrm{N} 2}=0.426 \mathrm{Y}_{\mathrm{CH} 4}=12.11 \mathrm{Y}_{\mathrm{H} 2 \mathrm{O}}=$ $33.292 \mathrm{Y}_{\mathrm{H} 2 \mathrm{~S}}=0.36$

\section{Results and Discussion}

\section{Syngas Compositions Produced from Gasifiers}

Partial combustion of coal inside the gasifier produces raw syngas consisting of different gases. Some of these are re-burned again in the turbine, such as $\mathrm{CO}, \mathrm{H}_{2}$, and $\mathrm{CH}_{4}$. Some are disposed off, including $\mathrm{H}_{2} \mathrm{~S}$. Some species will withdraw heat from the system, such as $\mathrm{N} 2$ and water. Some gases such as $\mathrm{CO}_{2}$ are harmful to the environment. Tables 6,7 , and 8 give the raw syngas compositions, as obtained from the above calculations, for all coal ranks, for the three studied gasifiers.

The numbers in Tables 6, 7, and 8 indicate the mole percentage of each gas component produced in the syngas by the partial combustion of coal. The mass ratio of each gas was not calculated, and it was sufficient to adopt the mole percentage values because they are more precise in expressing the gas composition since the mole mass for each gas species is different.

Table 6: Table 6: Syngas composition from entrained flow gasifier.

\begin{tabular}{|c|c|c|c|c|}
\hline \multirow{2}{*}{ Gas composition } & \multicolumn{4}{|c|}{ Coal rank } \\
\cline { 2 - 5 } & Anthracite & Bituminous & Sub bituminous & Lignite \\
\hline $\mathrm{CO} \%$ & 58.792 & 52.958 & 49.304 & 42.926 \\
\hline $\mathrm{CO}_{2} \%$ & 7.564 & 6.814 & 6.344 & 5.523 \\
\hline $\mathrm{H}_{2} \%$ & 30.126 & 38.075 & 31.33 & 03.418 \\
\hline $\mathrm{N}_{2} \%$ & 0.2 & 0.358 & 0.556 & 0 \\
\hline $\mathrm{CH}_{4} \%$ & 0 & 0 & 0 & 0.111 \\
\hline $\mathrm{H}_{2} \mathrm{~S} \%$ & 0.2 & 0.478 & 12.354 & 0.29 \\
\hline $\mathrm{H}_{2} \mathrm{O} \%$ & 3.118 & 1.315 & & 26.502 \\
\hline
\end{tabular}

Table 7: Syngas composition from fluidized bed gasifier.

\begin{tabular}{|c|c|c|c|c|}
\hline \multirow{2}{*}{ Gas composition } & \multicolumn{4}{|c|}{ Coal rank } \\
\cline { 2 - 5 } & Anthracite & Bituminous & Sub bituminous & Lignite \\
\hline $\mathrm{CO} \%$ & 47.121 & 42.33 & 39.533 & 10.716 \\
\hline $\mathrm{CO}_{2} \%$ & 12.773 & 11.474 & 33.314 & 26.318 \\
\hline $\mathrm{H}_{2} \%$ & 32.561 & 40.428 & 0.555 & 0.338 \\
\hline $\mathrm{N}_{2} \%$ & 0.198 & 0.356 & 3.553 & 3.096 \\
\hline $\mathrm{CH}_{4} \%$ & 4.235 & 3.805 & 0 & 0 \\
\hline $\mathrm{H}_{2} \mathrm{~S} \%$ & 0 & 0 & 12.326 & 26.463 \\
\hline $\mathrm{H}_{2} \mathrm{O} \%$ & 3.11 & 1.605 & & \\
\hline
\end{tabular}

Table 8: Syngas composition from fixed bed gasifier.

\begin{tabular}{|c|c|c|c|c|}
\hline \multirow{2}{*}{ Gas composition } & \multicolumn{5}{|c|}{ Coal rank } \\
\cline { 2 - 5 } & Anthracite & Bituminous & Sub bituminous & Lignite \\
\hline $\mathrm{CO} \%$ & 68.047 & 58.79 & 53.706 & 44.978 \\
\hline $\mathrm{CO}_{2} \%$ & 3.867 & 3.341 & 3.052 & 2.556 \\
\hline $\mathrm{H}_{2} \%$ & 4.88 & 18.775 & 11.773 & 0.269 \\
\hline $\mathrm{N}_{2} \%$ & 0.276 & 0.477 & 0.726 & 0.426 \\
\hline $\mathrm{CH}_{4} \%$ & 18.324 & 15.831 & 14.462 & 12.11 \\
\hline $\mathrm{H}_{2} \mathrm{~S} \%$ & 0.276 & 0.636 & 0.145 & 0.365 \\
\hline $\mathrm{H}_{2} \mathrm{O} \%$ & 4.327 & 2.148 & 16.133 & 33.292 \\
\hline
\end{tabular}

As seen the main components of the syngas are the two reactive species $\mathrm{H}_{2}$ and $\mathrm{CO}$ in addition to some $\mathrm{CH}_{4}$ and $\mathrm{CO}_{2}$. The syngas composition depends significantly, as show in Tables 6,7 , and 8 , on the gasification process and the coal rank. Each gasification technology has its own gasifier design with a specific chemical reaction and operating conditions. Coals have different constituents and chemical and physical properties. All these justify dependence of syngas composition on the gasifier type and coal rank. Syngas composition depends on other factors, such as coal preparation and its particle size, coal and gas residence time in the gasifier, coal feeding procedure whether dry or slurry, heating rate, flow directions, method of mineral removal (dry ash or slag), heat generation source, and operating temperature and pressure. No one gasifier or coal type will satisfy the desired application or 
syngas composition and it is a matter of compromise and trade off. It is seen from the above results that the entrained flow gasifier produces a satisfactory syngas composition with varying values for different coal ranks.

The main aim of combusting syngas is the production of heat and to result in less emissions. To generate high combustion, heat the fed syngas to the gas turbine should be rich in $\mathrm{H}_{2}$ and $\mathrm{CO}$ in addition to light hydrocarbons. The syngas should contain minimum or no $\mathrm{CH}_{4}$ and sulphur in order to reduce emissions. Less sulfur means significantly lower SOx emissions than that from conventional power systems.

The composition of syngas immensely influences the emission levels. The combustion of $\mathrm{H}_{2}$ and $\mathrm{CO}$ gases result in higher combustion temperature which favours thermal NOx formation. NOx can be either thermal (30\%) or fuel (70\%). However, such higher temperatures lead to complete combustion and hence reduces emissions of organic volatile matter which are traces of hydrocarbons in the syngas. NOx formation is a concerning issue in burning fuels whether fossil or syngas. To reduce fuel NOx, which constitutes the higher percentage of the total NOx, the nitrogen content in syngas should be small in addition to reducing the contact time between the fixed $\mathrm{N}_{2}$ in fuel and $\mathrm{O}_{2}$ in the combustion air. Various technologies are already available to reduce thermal NOx, e.g. flue gas recirculation (FGR) and staged combustion which reduces also fuel NOx.

Syngas combustion is greatly affected by the content of $\mathrm{H}_{2}$ in it. The burning velocity increases with the existed amount of $\mathrm{H}_{2}$ because the density is much less compared with that of natural gas. Also increasing the $\mathrm{H}_{2}$ content in syngas increases the flame stability. The presence of $\mathrm{CH}_{4}$ in syngas reduces the peak flame temperature but increases the prompt NO significantly.

The raw syngas produced from gasifiers needs a cleaning system in case used as fuel for a gas turbine in an IGCC plant.
Cleaning syngas means the removal of particulate matter, metallic compounds, and other undesirable pollutants such as sulphur. The cleaning system may be pre-combustion or post-combustion. A water gas shift system may be included to enhance the $\mathrm{H}_{2}$ content in the gas. $\mathrm{A} \mathrm{CO}_{2}$ capture system can be employed if desired. Therefore, IGCC plants are more environmentally cleaner than current ones especially if $\mathrm{CO}_{2}$ capture system is adopted.

It should be realized that there are many technological problems which should be encountered for a successful IGCC technology. The most important issue is the gas turbine which is the core of a combined cycle system. The differences in the properties between syngas and NG dictate new considerations in the design of the gas turbine in an IGCC system. For instance, the lower calorific value of syngas fuels requires a significant increase in the mass flow rate of fuel supply to the gas turbine as compared with burning NG. As a result the output power will increase and this needs a different design of the turbine to allow for the increased flow rate. Also the higher content of $\mathrm{H}_{2}$ in syngas which has a higher flame velocity may lead to difficulties in controlling the combustion mechanism. Also, syngas combustion is different from NG because of the presence of $\mathrm{H}_{2}$ and $\mathrm{CO}$ which have higher adiabatic flame temperatures than $\mathrm{CH}_{4}$. So, new issues should be looked after for a proper reliable gas turbine performance.

\section{Cold Gas Efficiency}

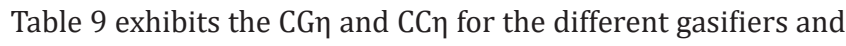
coals. Figure 6 lists some cold gas efficiencies for various gasification processes for all coal ranks. The cold gas efficiency is the ratio of fuel heat content to the syngas heat content at ambient conditions and is a measure of how efficiently fuel energy is converted into syngas energy. For the cases reported, the fixed bed is most efficient but has the disadvantage that some of the syngas energy is produced in tars. The listed efficiencies ( $86 \%)$ support the rule of thumb that approximately $15 \%$ of the feedstock heating value is used to convert the feedstock to syngas.

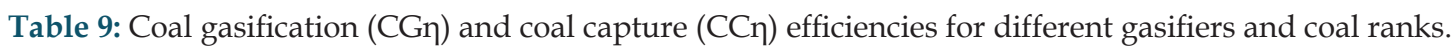

\begin{tabular}{|c|c|c|c|c|c|c|}
\hline \multicolumn{7}{|c|}{ Gasifier } \\
\hline \multirow{2}{*}{ Coal } & \multicolumn{2}{|c|}{ Entrained flow } & \multicolumn{2}{|c|}{ Fluidized bed } & \multicolumn{2}{|c|}{ Fixed bed } \\
\hline & $(\mathrm{CG \eta})$ & $(\mathrm{CC} \eta)$ & $(\mathrm{CG} \eta)$ & $(\mathrm{CC} \eta)$ & $(\mathrm{CG \eta})$ & (CC $\eta)$ \\
\hline \multicolumn{7}{|c|}{$\%$} \\
\hline Anthracite & 82.22 & \multirow{4}{*}{100} & 84.76 & \multirow{4}{*}{97} & 86.92 & \multirow{4}{*}{98} \\
\hline Bituminous & 81.72 & & 84.23 & & 85.88 & \\
\hline Sub- bituminous & 80.31 & & 82.57 & & 84.59 & \\
\hline Lignite & 78.32 & & 80.83 & & 82.66 & \\
\hline
\end{tabular}




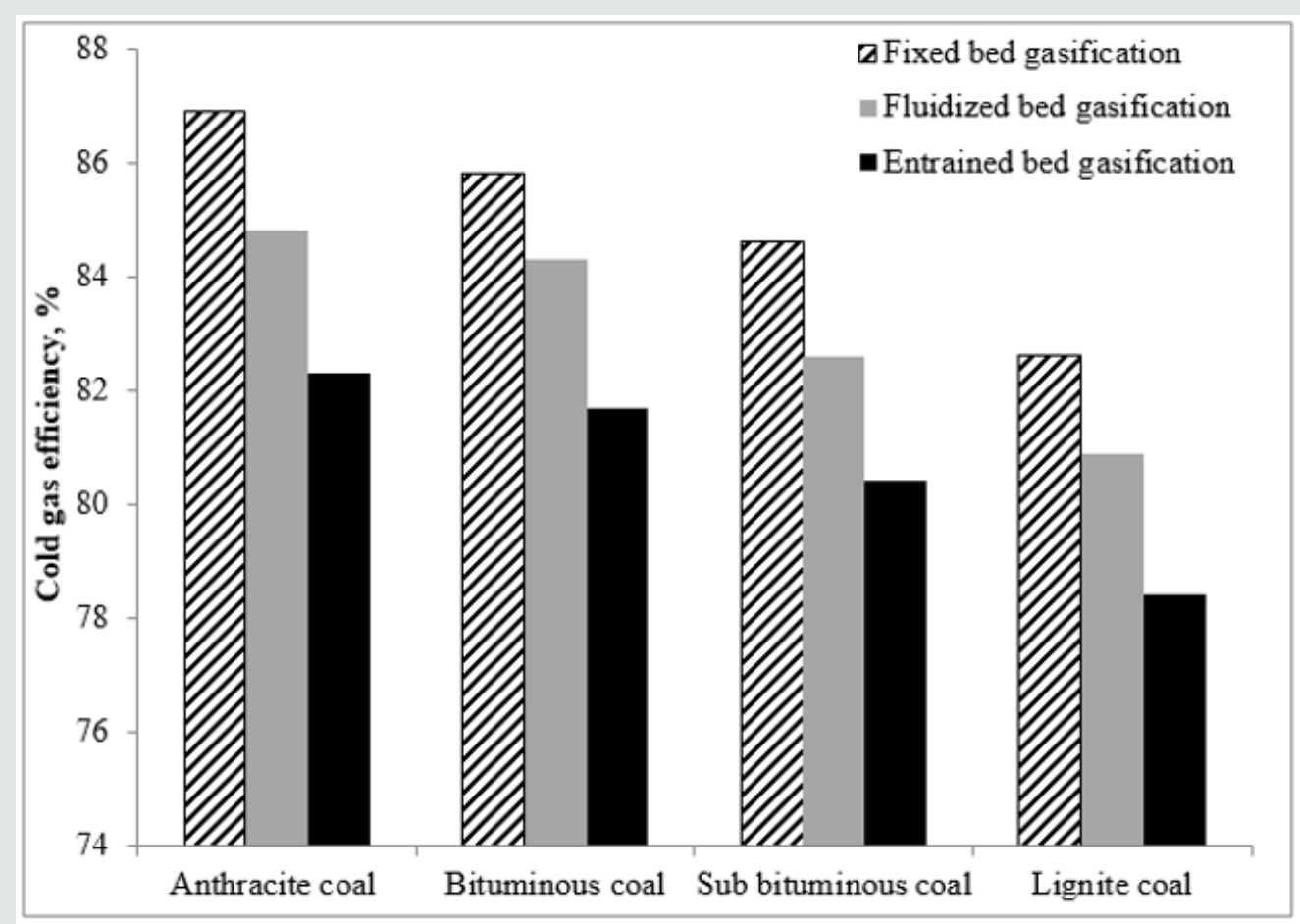

Figure 6: Cold gas efficiency, \%.

The results depict that the entrained flow gasifier, for all coal ranks, is the predominant one because of its low cold gas efficiency which means low loses in coal fired because of the high temperature in the gasifier, higher carbon conversion efficiency (100\%), low tar, and the low methane produced which means lower emission. The second good, for all coal types, is the fluidized bed gasifier.

\section{Conclusions}

Irrespective of new discoveries of natural gas reserves and new techniques (such as hydraulic fracturing or fracking) being developed to increase cheaper natural gas production, coal will continue to be a major energy source to produce electricity in the world, either for economic reasons or as a strategy to safeguard national energy security and independence. The conventional way of burning coal is environmentally unfriendly; therefore, it is essential that cleaner methods of utilizing coal be developed. IGCC is one of the most promising methods to generate electricity in a more efficient, environmentally friendly manner than conventional fossil fuel plants. Example step by step manual calculation procedure was conducted for one coal (bituminous).

Syngas composition depends incredibly on the gasification process and coal type. Each gasification technology has its own specific chemical reaction and operating conditions. The entrained flow gasifier satisfies most of the requirements needed for the appropriate syngas for IGCC plants, for all coals. This gasifier produces raw syngas with zero $\mathrm{CH}_{4}$, high $\mathrm{H}_{2}$ and $\mathrm{CO}$, and low $\mathrm{CO}_{2}$, $\mathrm{H}_{2} \mathrm{O}, \mathrm{N}_{2}$, and $\mathrm{H}_{2} \mathrm{~S}$.
The entrained flow gasifier is the most viable of the three because of its high carbon conversion efficiency which means low loses in coal fired and low cold gas efficiency, high temperature in the gasifier, low tar, and low methane produced resulting in low emissions, and it produces a clean gas in such a short time because of the employed high temperature. Compare this with a countercurrent fixed-bed process, which uses lump coal, the heating up rate is slow with a built up of high volatiles concentration that are removed unreacted from the reactor by the syngas.

For the technology of IGCC plants to be competitive and economically feasible, their availability should be increased and the capital cost to be reduced. Achieving these, IGCC systems will be fully commercial and of increased widespread use (table 10).

Table 10.

\begin{tabular}{|c|c|c|}
\hline Symbol & Description & Unit \\
\hline $\mathrm{M}$ & Molar weight & gm $/ \mathrm{mole}$ \\
\hline$\dot{\mathrm{m}}$ & Mass flow rate & Tone per day (TPD) \\
\hline $\mathrm{T}$ & Temperature & 0C , K \\
\hline HHV & High heating value & $\mathrm{MJ} / \mathrm{kg}$ \\
\hline $\mathrm{LLV}$ & Low heating value & $\mathrm{MJ} / \mathrm{kg}$ \\
\hline $\mathrm{CG \eta}$ & Cold gas efficiency & $\%$ \\
\hline $\mathrm{CC} \eta$ & Carbon conversion efficiency & $\mathrm{MW}$ \\
\hline$\Delta \mathrm{HC}$ & Heat of syngas & - \\
\hline FT & Fischer-Tropsch & - \\
\hline IGCC & Integrated gasification combined cycle & - \\
\hline ASU & Air separation unit & - \\
\hline WGS & Water-gas shift & \\
\hline
\end{tabular}




\section{Conflict of Interest}

The authors declare that there is no conflict of interest regarding publication of this paper.

\section{References}

1. Rafael Luque, James G Speight (Eds) (2015) Gasification for synthetic fuel production: Fundamentals, processes, and applications. Woodhead Publishing Series in Energy, Cambridge, England.

2. Ting Wang, Gary J Stiegel (Eds) (2016) Integrated gasification combined cycle (IGCC) technologies, $1^{\text {st }}$ Edition. Woodhead Publishing, Cambridge, England.
3. Christopher Higman, Maarten vanderBurgt (2003) Gasification. Second Edition. Elsevier Science Publisher, Amsterdam, Netherlands.

4. Yatish TShah (2017) Chemical energy from natural and synthetic gas. Florida: CRC Press. Taylor and Francis group publisher.

5. Tim Lieuwen, Vigar young, Richard Yetter (Eds) (2009) Synthesis gas combustion fundamentals and applications, $1^{\text {st }}$ Edition. CRC Press, Taylor and Francis group publisher, Florida, USA.

6. Jeffrey Phillips (2006) Different types of gasifiers and their integration with gas turbines: The Gas Turbine Handbook. US Department of Energy Publisher, Washington DC, USA.

7. Yong seung Yun (Ed) (2012) Gasification for practical applications. $1^{\text {st }}$ Edition. Intech Open Publisher, London, United Kingdom.
(C) This work is licensed under Creative

To Submit Your Article Click Here: Submit Article

DOI: $10.32474 / J O M M E .2020 .01 .000109$

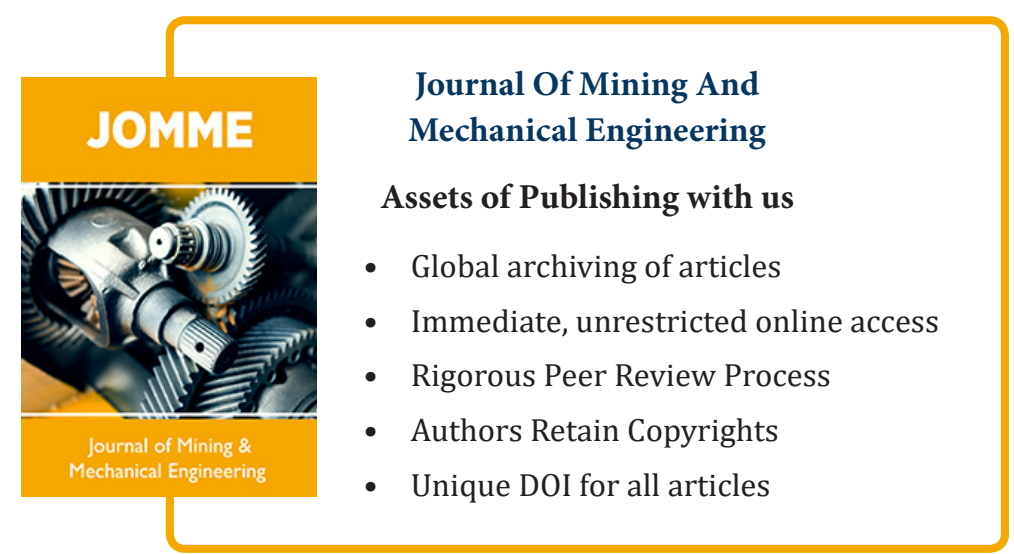

